\title{
The Occurrence of Potentially Pathogenic and Antibiotic Resistant Gram-Negative Bacteria Isolated from the Danube Delta Ecosystem
}

\author{
Alina R. Banciu ${ }^{1}$, Daniela L. Ionica ${ }^{1}$, Monica A. Vaideanu ${ }^{1,2}{ }^{\text {, Dragos M. Radulescu }}{ }^{1,3}$, Mihai Nita-Lazar ${ }^{1}$ \\ and Cristina I. Covaliu $4, *$ \\ 1 National Research and Development Institute for Industrial Ecology-ECOIND, \\ 71-72 Drumul Podu Dambovitei, 060652 Bucharest, Romania; alina.banciu@incdecoind.ro (A.R.B.); \\ daniela.ionica@incdecoind.ro (D.L.I.); monica.vaideanu@ecoind.ro (M.A.V.); \\ dragos.radulescu@ecoind.ro (D.M.R.); mihai.nita@incdecoind.ro (M.N.-L.) \\ 2 Faculty of Biology, University of Bucharest, Splaiul Independentei 91-95, 050095 Bucharest, Romania \\ 3 Faculty of Ecology and Environmental Protection, Ecological University of Bucharest, 1G Vasile Milea Street, \\ 061341 Bucharest, Romania \\ 4 Faculty of Biotechnical Systems Engineering, University Politehnica of Bucharest, 313 Splaiul Independentei, \\ 060042 Bucharest, Romania \\ * Correspondence: cristina_covaliu@yahoo.com; Tel.: +40-0722791791
}

check for updates

Citation: Banciu, A.R.; Ionica, D.L.; Vaideanu, M.A.; Radulescu, D.M.; Nita-Lazar, M.; Covaliu, C.I. The Occurrence of Potentially Pathogenic and Antibiotic Resistant Gram-Negative Bacteria Isolated from the Danube Delta Ecosystem. Sustainability 2021, 13, 3955.

https://doi.org/10.3390/su13073955

Academic Editor: Hone-Jay Chu

Received: 13 February 2021

Accepted: 24 March 2021

Published: 2 April 2021

Publisher's Note: MDPI stays neutral with regard to jurisdictional claims in published maps and institutional affiliations.

Copyright: (c) 2021 by the authors. Licensee MDPI, Basel, Switzerland. This article is an open access article distributed under the terms and conditions of the Creative Commons Attribution (CC BY) license (https:// creativecommons.org/licenses/by/ $4.0 /)$.

\begin{abstract}
The spread of a growing number of antibiotic-resistant bacteria (ARB) outside the clinical setting into the environment has been observed. The surface water plays an important role in ARB dissemination by being both habitats and transport systems for microorganisms. The ecological and touristic importance of the Danube Delta make it a European priority for close monitoring of its freshwater system. The main goal of this paper was to analyze how the St. Gheorghe branch of the Danube Delta microbiological contamination and their antibiotic-resistant profile were influenced by climate change, especially the global warming from 2013 up to 2019. In the surface water from all sampling points, total and fecal coliform bacteria showed a constant colony forming units (CFU) increase tendency during the years, with a sharp rise from $1500 \mathrm{CFU} / \mathrm{mL}$ in 2015 to more than $20,000 \mathrm{CFU} / \mathrm{mL}$ in 2019. The bacterial population's analyses revealed an indirect proportionality between coliform bacteria density in water and sediment during the years in accordance with global warming. The most commonly identified bacterial strains such as Escherichia coli, Klebsiella oxytoca, Citrobacter freundii and Proteus mirabilis have been shown a resistance rate of approximatively $70 \%$ to beta-lactam antibiotics, especially to ampicillin and amoxicillin-clavulanate.
\end{abstract}

Keywords: bacteria; pathogenicity; antibioresistance; Danube Delta

\section{Introduction}

In the past few decades, the worldwide waterbodies' biological quality has deteriorated due to several factors such as human population growth and subsequently the increase of anthropic activities (agriculture, industry, medicine) and global warming [1,2]. The focus on the ecosystem ecology is a consequence of the changing paradigm direction of environmental management. Ecosystems are conceptual and functional units of study that entail the ecological community together with its abiotic environment [3]. The conditions of a tumultuous urbanization of the contemporary civilization have triggered issues linked to water resource pollution and an alarming process of ecological balance deterioration $[4,5]$. River networks fundamentally differ from most other ecosystems because they are open systems with tight functional linkages to their adjacent ecosystems. Moreover, there are systems that change their physical and ecological properties depending on the spatio-temporal and environmental conditions [6]. The characteristics of bacterial, viral and parasitic pathogens vary under environmental conditions, indicating that probably 
not a single indicator organism could predict the presence of all enteric pathogens for all types of water and link them to different host-associated fecal pollution. Microbiological methods and alternative fecal indicators have greatly enhanced the capabilities to predict and reduce the health risks associated with the use of surface waters [7]. Directly or indirectly, the water cycle allows microorganisms to move from an aquatic environment to another one, getting into the main sources of water. It is known that the 20th century was characterized by a significant acceleration of the pathogenic microorganism's evolution that culminated with antibiotic discovery, which exerts selective pressure onto bacterial populations [8-10]. The massive increase of antibiotic production and consumption is triggered by the development of antibiotic-resistant bacteria, especially for the coliforms from aquatic ecosystems [11]. In spite of the benefit of antibiotics, in clinical medicine and food animal production, the problem, especially that of commensal bacteria, lies in environmental factors and animal hosts, as well as in the emergence, dissemination and evolution of antibiotic resistance [12].

Microorganisms have the ability to populate all types of ecosystems where they could acquire antibiotic resistance through multiple genetic transfer mechanisms. Water is an important factor in the ecological balance and its pollution has become a problem with major implications on health population, especially when the aquatic system is part of a protected area such as the Danube Delta.

The Danube Delta is the only morphohydrological unit of its type for biosphere reservation. This area represents a particular case among the world's deltas: it is the most untamed delta in Europe. Moreover, it contains a great dammed surface which represents approximatively $31 \%$ of its total surface. This area is not flooded because the protection dams are higher than 10 hydrograde. Considering that discharges are constant, the water volume stored at a certain time in the deltaic space is related to a smaller surface that the surface before erecting the enclosing dams [13].

The Danube River is permanently subject to both natural and anthropogenic pressures. The quality of the river water is under great pressure from these activities with the participation of over 80 million people that generate large quantities of pollutants that the Danube River collects and transports to the mouth in the Black Sea through the Danube Delta [14].

According to Pall E. et al. 2013, in the Danube River basin total coliforms, fecal coliforms and Escherichia coli indicated persistent contamination of the highest values in the summer months. Variation of these parameters could be spatio-temporarily linked to the number of visitors in this ecosystem. The main problem that affects the water quality of the river is the high pollution along the Danube river following different human activities, as well as the population explosion. This phenomenon is raised on the deltaic ecosystem, too [15].

Europe's most valuable wetland isfacing several problems such as nutrient concentrations' organic pollution, toxic substances, invasive species and hydro morphological alterations [16]. Many efforts are directed to its monitoring and pollution management [17,18].

In the second half of the 20th century, St. Gheorghe branch of the Danube Delta was affected by important hydro technical works thatwere carried outin the natural meander's cutoff [19]. These structural changes caused the degradation of biotope quality by increasing the current velocity, massive organic deposition, accumulation of nutrient and pollutants, elevated fungal concentration and bacteria, often pathogenic. The high level of nutrients and pathogens that fecal pollution introduces to aquatic environments could have a negative impact on the receiving biota and overall ecosystem health [20]. Commonly the coliforms group demonstrated poor correlation with various pathogenic microorganisms. This could be partly explained by differences in survival and persistence of coliforms and pathogens in different water environments. The total coliforms are Gram-negative bacilli presented in a large number in the gut of humans and other warm-blooded animals. This means that if water is polluted by feces, coliforms can be detected even after extensive dilution. However, the total coliform group lacks specificity as many of them can exist and grow in both water and sediment. The presence of total coliforms in water may be theresult 
of natural processes and not of fecal pollution. With few exceptions, coliforms themselves are not considered to be a health risk, but their presence indicates that fecal pollution may have occurred, and pathogens might be present as a result [21]. Coliforms (fecal or not) may not only survive but could also become normal microbiota of the freshwater environment. Non-fecal sources such as flora and fauna from that particular area contribute in addition to human discharge fecal contamination to total coliforms population, too.

Moreover, limited data on correlation between levels of coliforms density and pathogens or incidence of diseases limit their use as a fecal pollution indicator. The surface water monitoring of microbial contamination is based on a single fecal indicator and it might not be a satisfactory occurrenceassessment of a particular enteropathogen [6]. Microbial indicators have been used worldwide as a tool to indicate the water body contamination by anthropogenic sources the emergence of antibiotic-resistant bacteria is predictable in any environment where antibiotics are released. Many antibiotics persist in the sediment and in the aquatic environment [22]. Water dissolves industrial antibiotics and particles binding to sediment delay its biodegradation and explain long-term permanence of the drugs in the ecosystems [23].

Beta-lactam agents such as Ampicillin (AMP) and Amoxicillin-Clavulanate (AMC) are among the most frequently prescribed antibiotics worldwide. In Gram-negative pathogens, beta-lactamases remain the most important contributing factor to beta-lactam resistance. Beta-lactamases are bacterial enzymes that inactivate beta-lactam antibiotics by hydrolysis, which results in ineffective compounds [24].

According to ECDC (European Centre for Disease Prevention and Control), a significant consumption of antibiotics was recorded in Romania in 2019, both in the medical sector and in the community. The consumption of antibacterials for systemic use in the community in 2019 classified Romania on an orange code with 22.92-27.66 DDD (defined daily dose) per 1000 inhabitants per day. At the same time, there was an upward trend for the ratio of consumption of broad-spectrum penicillins, cephalosporins, macrolides (except erythromycin) and fluoroquinolones to the consumption of narrow-spectrum penicillins, cephalosporins and erythromycin in the community [25].

The aim of the present study was to emphasize the presence of Gram-negative bacterial group and their antibiotic resistance in the Danube Delta aquatic system. The St. Gheorghe branch of the Danube river, which carries out $22 \%$ of the water and sediment volume, was chosen as study area for this study. Nine control sections were established in order to highlight human pressure over the ecosystem functioning. The main objectives aimed atthe presentation of the fecal pollution degree, as well as the isolation and identification of potentially pathogenic bacteria and antibiotic resistance profile in the years of 2013, 2015 and 2019 in the aquatic ecosystem of St. Gheorghe branch.

\section{Materials and Methods}

\subsection{Sampling}

Nine sampling locations were selected between Isaccea and the Black Sea: one on the Danube River (S1-Isaccea), two on Tulcea branch (S2-Upstream Tulcea and S3-Downstream Tulcea) and six (S4-S6) on St. Gheorghe branch (Figure 1). The location of sampling sites was selected based on St. Gheorghe branch morphological changes and environmental factors such as different construction alongside meander's modification that produced major changes in the sediment distribution, the extension of socio-economical activities of tourism, the potentially impact of flood.

The surface water and sediment samples were collected each season (winter, spring, summer and autumn) during 2013, 2015 and 2019. The freshwater samples were collected from the most upper-most water layer in triplicates in sterile containers of $1 \mathrm{~L}$ according to ISO 19458 [26]. The sediment samples were taken from 3 control points of each according to Stoica et al. 2014a,b [17,18]. A van Veen grab was used for sediment collection at a depth of about $10 \mathrm{~cm}$. The sediment samples were homogenously collected in a sterile container 
of $500 \mathrm{~mL}$. The samples were transported in the isothermal boxes at $4-5{ }^{\circ} \mathrm{C}$ and analyzed immediately after receiving the samples in the laboratory.

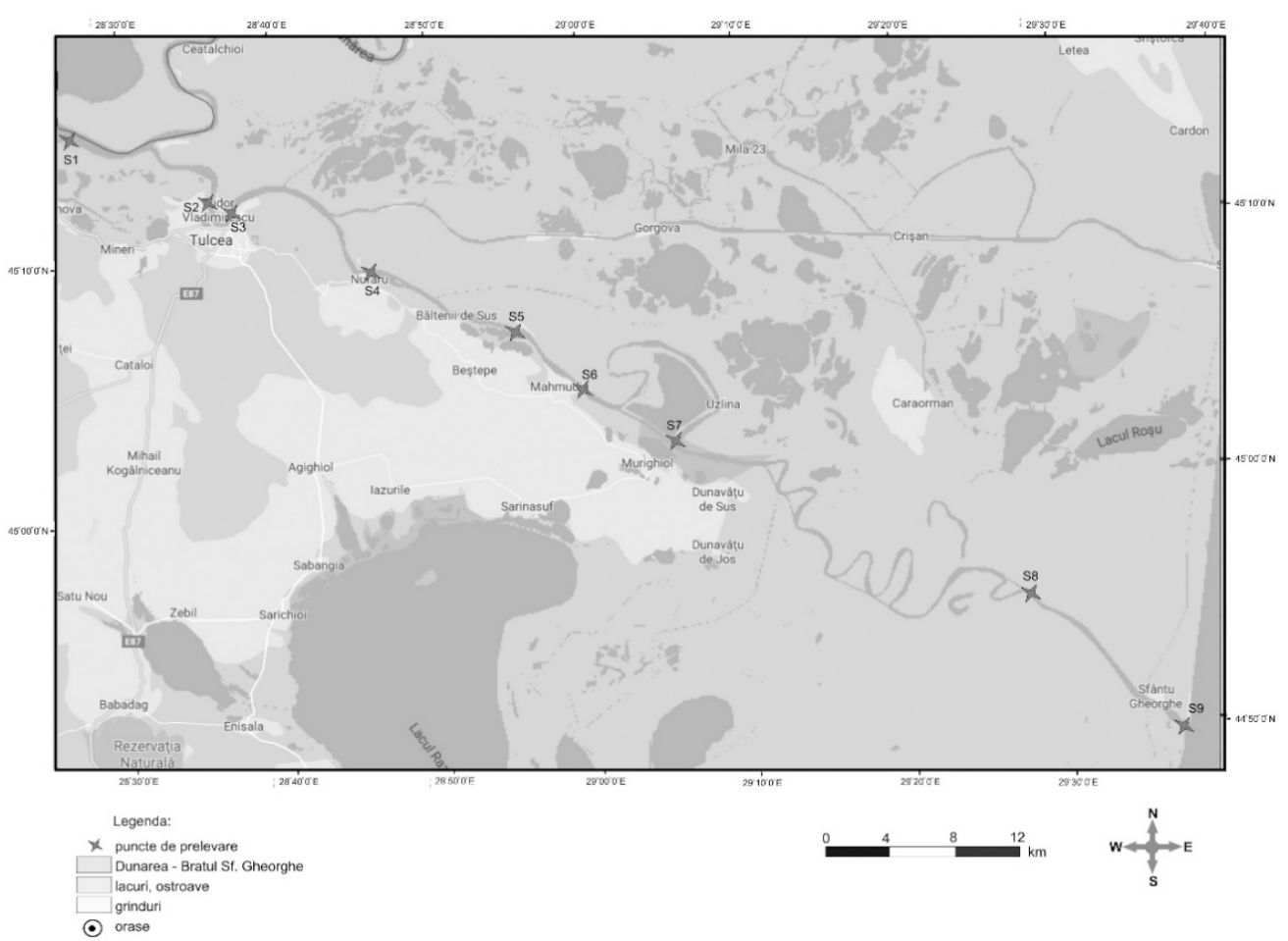

Figure 1. The sampling sites on the St. Gheorghe Branch (S1 = Iscaccea, S2 = Upstream Tulcea, S3 = Downstream Tulcea, S4 = Nufaru, S5 = Balteni, S6 = Mahmudia, S7 = Murighiol, S8 = Ivancea, S9 = Black Sea confluence).

\subsection{Microbiological Analysis}

The densities of total coliform and fecal coliform bacteria from the surface water and sediment samples were performed in duplicate by Most Probable Number (MPN) method (IDEXX) [27], using Colilert-18 medium and incubate the samples at $36 \pm 2{ }^{\circ} \mathrm{C}$ for $18-22 \mathrm{~h}$ (total coliforms) and $44.5^{\circ} \mathrm{C}$ for $18-22 \mathrm{~h}$ (fecal coliforms). The positive control (Escherichia coli ATCC25922, Citrobacter freundii ATCC 8090 and Enterobacter aerogenes ATCC 13048) and the negative one (Enterococcus faecalis ATCC 29212) were tested. At the same time, a blank control with sterile distilled water was analyzed. The results were represented by the average of replicates from each sample, and they were expressed in CFU / $100 \mathrm{~mL}$ for both water and sediment samples.

The identification of Enterobacteriaceae strains was based on metabolic reactions with the Omnilog automated system (Biolog, Harward, CA, USA). It has 96 well MicroPlates that incorporate a patented Redox tetrazolium dye that changes color as a result of cellular respiration providing a metabolic fingerprint from a database through a software.

All pathogenic or potentially pathogenic bacteria, based on their known virulence and pathogenic characteristics, were selected for antibiotic profile tests.

The susceptibility testing was performed in duplicate by disk diffusion method on Muller-Hinton agar (Oxoid, Basingstoke, Hants, UK). The antibiograms were performed according to CLSI recommendations [28] with 6 beta-lactam antibiotics such as $30 \mu \mathrm{g}$ Amoxicillin clavulanate $30 \mu \mathrm{g}$ (AMC), $30 \mu \mathrm{g}$ Ceftazidime (CAZ), $30 \mu \mathrm{g}$ Ceftriaxone (CRO), $30 \mu \mathrm{g}$ Cefepime (FEP), $10 \mu \mathrm{g}$ Ampicillin (AMP) and also $10 \mu \mathrm{g}$ Imipenem (IMP).

\section{Results and Discussion}

The global temperature has been oncontinuous rise during the years, affecting the Oceans as well as the continents (Figure 2). Pollution, especially greenhouse gases, hasbeen 
most responsible for such a tremendous temperature raise in such a short time. Overall, global temperature raised almost $2{ }^{\circ} \mathrm{C}$ in only 7 years, from the beginning of 2013 up to 2019 [29].

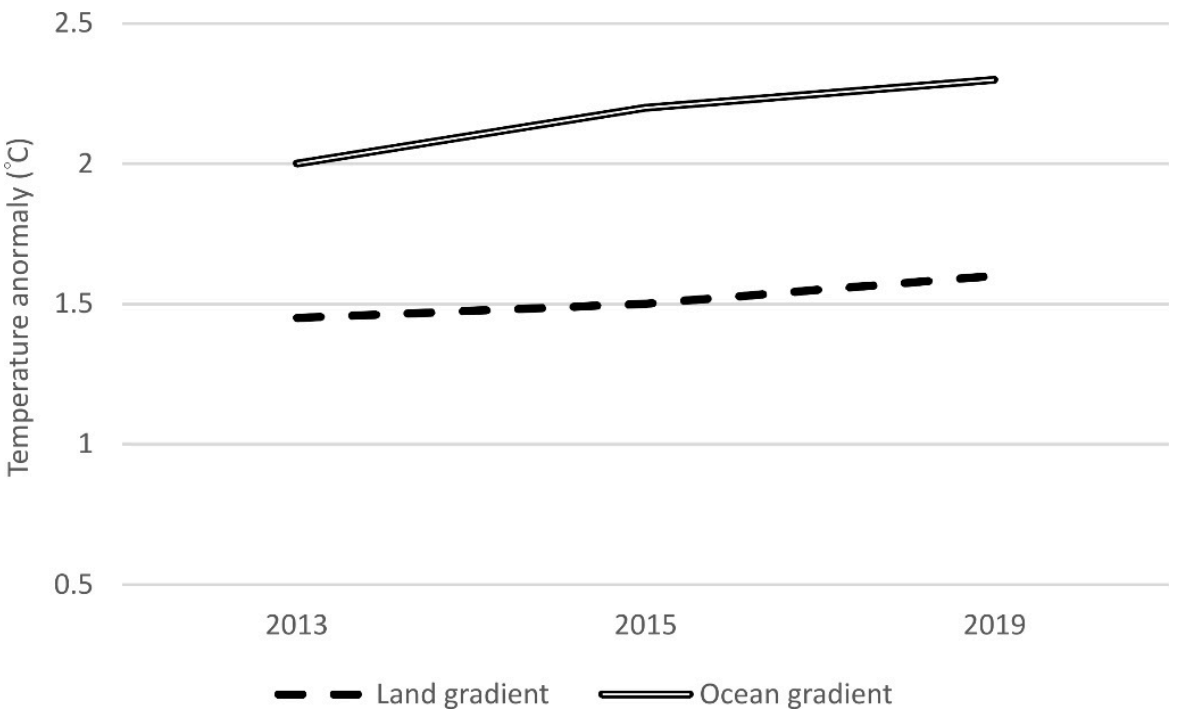

Figure 2. Variation of the global temperature gradient on land and ocean between2013-2019 [29].

Berkeley Earth, a California based research organization, concluded that 2019 was the second warmest year on Earth since 1850. The global mean temperature was estimated to be $1.28^{\circ} \mathrm{C}$ above the average temperature of the late of 19 th century (Global Temperature Report for 2019-Berkeley Earth). The year 2019 was also the warmest year in Romania with high temperatures and drought especially in the south of the country where the area of interest for this study is located.

The average temperature measured on St. Gheorghe branch during the studied period matched the trendline of the global temperature variation (Figure 2) which will be further linked with the microbiological development trendline.

Numerous studies have shown that individual bacterial populations are highly dynamic in response to seasonal cycles and chemical factors may trigger changes in the bacterial composition and therefore affecting water quality [29-33]. Similarly, seasonal shifts in water column stability and water temperature may demonstrate an annual pattern of bacterial community variability, against the background of global warming during 2013-2019 (Figure 2). According to JDS (The Joint Danube Survey), the microbiological parameters are very important for Danube river water quality classification in five classes of pollution: little, moderately, critical, strongly and excessively pollution. Based on samples harvested from Romanian's Danube Delta, strongly fecal class was observed [8]. Organisms in this type of pollution are potentially pathogenic or pathogenic bacteria with gastro-intestinal habitat that can trigger infectious processes in the human body [34,35].

The location of sampling sites was selected based on St. Gheorghe branch morphological changes and environmental factors [17,18]. In aquatic systems the detection and counting of all pathogenic Gram-negative microorganisms potentially present were impossible due to a large diversity of the pathogens and methods based on kits for the detection of each of them [36,37]. Thus, for monitoring fecal indicator enterobacteria were analyzed to evaluate the level of microbial water contamination (Figure 3). The total coliforms densities (CFU/mL) in the surface water (Figure 3a) were at the highest level in 2019, trending upwards from 2019, which correlated with global warming (Figure 2). The statistical evaluation of results (Figure 3a) showed an annual average of 895 CFU/100 mL for total coliforms in surface water in 2013 which reached 32,268 CFU/100 mL in 2019. The ratio between total coliforms and fecal coliforms changed from 2 in 2013 (895 CFU/100mL total coliforms vs. $429 \mathrm{CFU} / 100 \mathrm{~mL}$ fecal coliforms) to 1.4 in 2019 (32,268 CFU/100mL total 
coliforms vs. 23,120 CFU/100 mL fecal coliforms). These results showed that other possible bacterial strains started to develop when the temperature raised. On the opposite, the average total bacteria from sediments decreased with the temperature raise and the ratio between total coliforms vs. fecal coliforms decrease up to 1 (Figure 3b). The results showed that in 2013 around $60 \%$ of the total coliforms were fecal coliforms, but in 2019 almost all the total coliforms were composed of fecal coliforms.

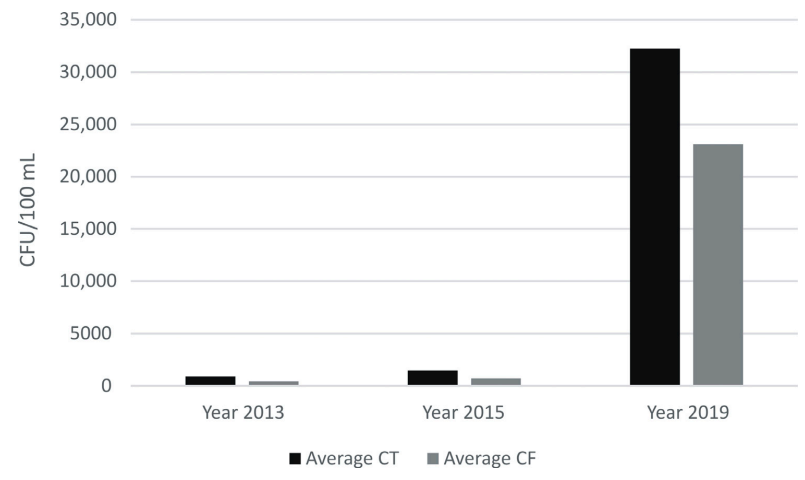

(a)

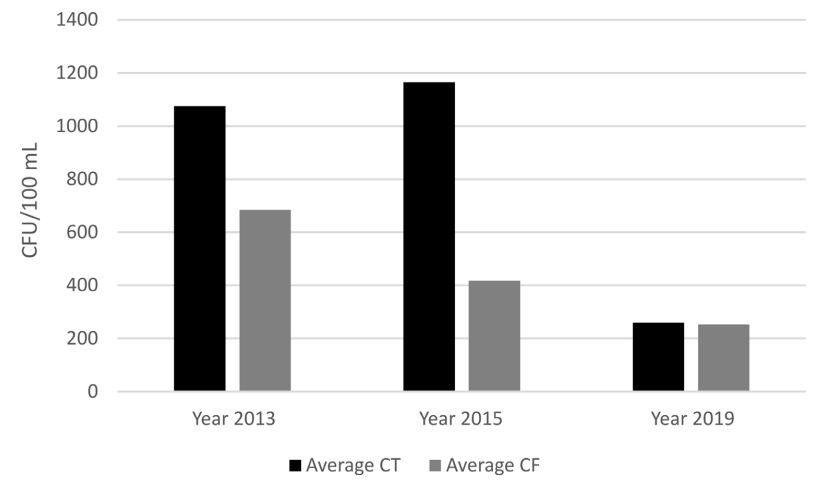

(b)

Figure 3. Temporal variation of total coliform bacteria (CT) and fecal coliform bacteria (CF) densities (annual averages) in the surface water (a) and sediment (b) from St. Gheorghe branch during 2013-2019. The densities of total and fecal coliform bacteria (CFU/100 mL) were seasonal quantified in all 9 sampling sites (S1 to S9) during all three sampling periods.

These results could be explained by the impact of the human population, industrial and agricultural growth, pollution and temperature thathighly contributed to wastewater discharge into the environment and the structural modification of the bacterial population. Similar arguments werealso presented by Anna Lenart-Boron et al. 2017 on the water quality of rivers in Podhale, Poland [38].

In the next step, the microbiological analysis was carried out on each sampling to pinpoint the pollution hot spots along the Delta of Danube.

Overall, the results showed a massive increase intotal coliforms densities in surface water from 2013 to 2019 for all sampling sites (Figure 4A). Amajor gap was created between 2015 and 2019 and it could correlate with global warming. Analyzing the potential pollution hot spots in 2019, a sharp growth of the bacterial density from 7576 CFU / 100mL at S2 (upstream town of Tulcea) to $9150 \mathrm{CFU} / 100 \mathrm{~mL}$ at S3 (downstream Tulcea) could be observed, then to $36,580 \mathrm{CFU} / 100 \mathrm{~mL}$ at $\mathrm{S} 4$ (town of Nufarul). The difference between S2 and S3, up to 1574 CFU/100mL could be explained by the microbiological pollution generated by Tulcea town. Furthermore, Nufarul (S4) seemed to generate an important microbiological pollution to Danube, up to $227,430 \mathrm{CFU} / 100 \mathrm{~mL}$. This phenomenon can be explained by the location of rural houses on the waterfront. Therefore, it can be considered a point pollution caused by the direct discharge of wastewater into the natural emissary.

The other counties from S5 to S7 seemed to generate a much smaller amount of microbiological pollution, keeping the microbiological contamination at around 42,000 CFU/100mL.

The decrease in the microbial contamination at S8 (Ivancea's town) to $29,760 \mathrm{CFU} / 100 \mathrm{~mL}$ could the explained by the hydrological work at that area which created meanders and a direct drainage channel. Most of the heavily microbiological contaminated upstream water passed through the channel without contaminating the meanders (sampling point S9).

S9 seemed to have the highest bacterial contamination, most likely due to the addition of the bacterial contamination from the Black Sea, 84,550 CFU/100 mL at the Black Sea confluence. 


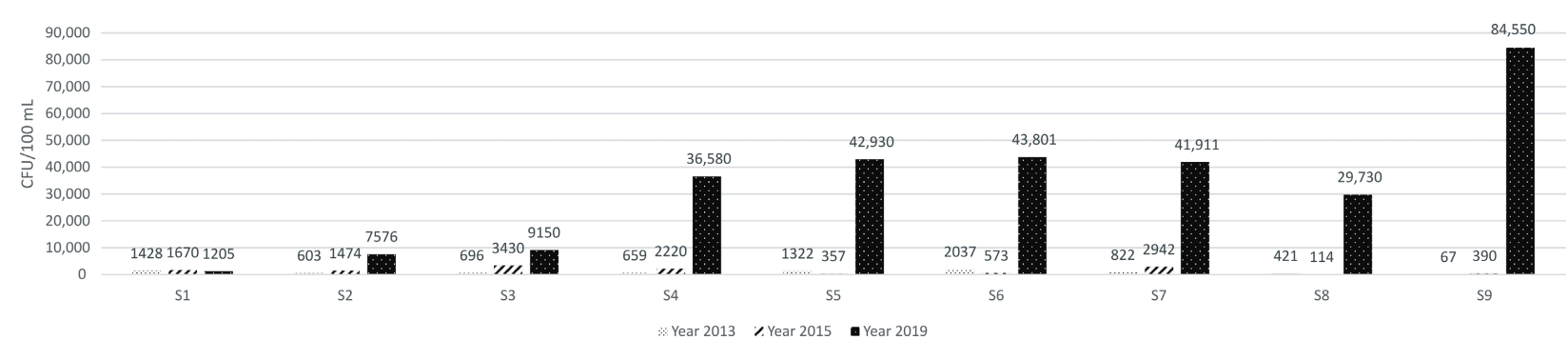

(A)

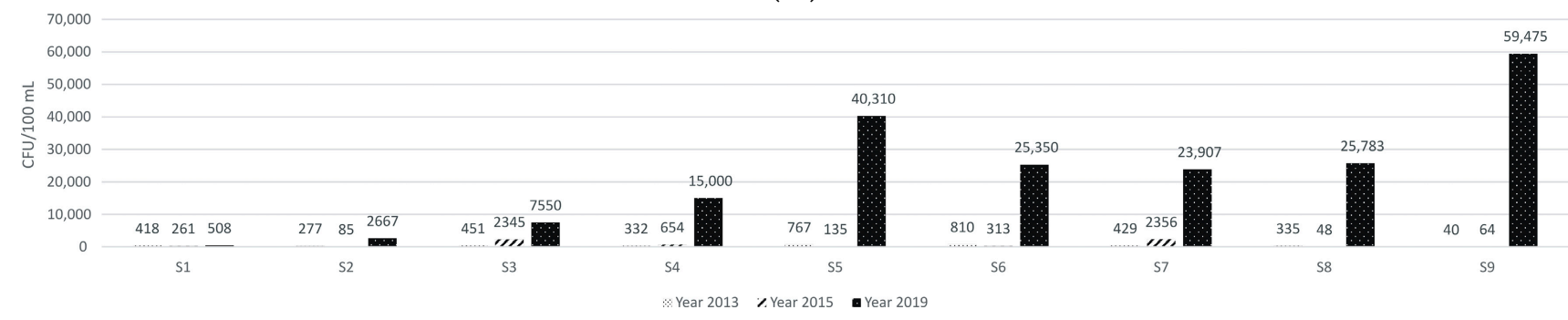

(B)

Figure 4. Spatial and temporal variation of total (A) and fecal (B) coliform bacteria densities of each sampling section from Sf. Gheorghe branch (S1 to S9) in surface water in 2013, 2015 and 2019. All studies represent one of three independent experiments.

Overall, during 2013 and 2015, the total coliforms densities remained at very low densities (CFU /100mL) for all sampling sites S1-9, up to 1428 CFU / $100 \mathrm{~mL}$ in 2013 and up to $3430 \mathrm{CFU} / 100 \mathrm{~mL}$ in 2015.

The low bacterial densities could be associated with "good" ecological status of Danube Delta (St. Gheorghe Branch) based on chemical quality elements (oxygen regime, nutrients) previously reported by Stoica et al. (2016) [17]. They emphasized that during 2013, the pH values ranged between 6.65 at S6 (Mahmudia) to 8.23 at S3 (Downstream Tulcea). In terms of oxygen regime, $10 \%$ percentile applied on the oxygen concentrations measured during 2013 showed that lowest values of $6.95 \mathrm{mgO}_{2} / \mathrm{L}$ at $\mathrm{S} 1$ (Isaccea), $7.01 \mathrm{mgO}_{2} / \mathrm{L}$ at S2 (Upstream Tulcea), $7.56 \mathrm{mgO}_{2} / \mathrm{L}$ at S3 (Dowstream Tulcea), $7.95 \mathrm{mgO}_{2} / \mathrm{L}$ at S5 (Balteni) and $7.76 \mathrm{mgO}_{2} / \mathrm{L}$ at S7 (Murighiol) were below the very good/good ecological status. Similarly, this fact was also observed in case of nutrients, for instance of $\mathrm{N}^{-\mathrm{NO}_{3}}$ concentrations, where the highest values of $90 \%$ percentile calculated during 2013 were recorded in almost the same sampling sites (S3, S7 and S9) [17]. Thus, in particular, it was observed that bacterial densities detected in freshwater samples along St. Gheorghe Branch varied depending on punctiform pollution sources (industrial and domestic wastewater discharges, touristic activities and agricultural runoff). The oxygen regime decrease might have beencaused by the total suspended solids increase (data not shown), which could correlate with the organic debris generated by microbial communities [39].

It is worth mentioning that fecal coliform bacteria contamination (Figure 4B) had the same pattern as the total coliform bacteria (Figure 4A). Moreover, the rapport between total and fecal coliform bacteria seems to be up to 2:1 with the exception of S3, S5 and S8 where this rapport was close to 1.1:1 (Figure 4). It seemed that in that locations the fecal contamination contributed up to $93 \%$ to the total coliforms amount.

It was interesting to point out that the microbial contamination pattern in sediments over the time (2013-2019) was opposite to the total coliform surface water pattern (Figure 5). It seemed that the bacteria contamination from sediments decreased with global warming. This phenomenon can be explained by the need for bacteria of a larger quantity of nutrients. The experiments of Christian B.W. end Lind O.T. 2007 mentioned that organic carbon utilization by heterotrophic bacteria influenced internal nutrient cycling in freshwater ecosystems. Therefore, bacterial populations moved from water to sediment and the other way around depending on the nutritional conditions that vary with increasing or decreasing temperature, and with the contribution of organic load from punctual discharges [40]. 


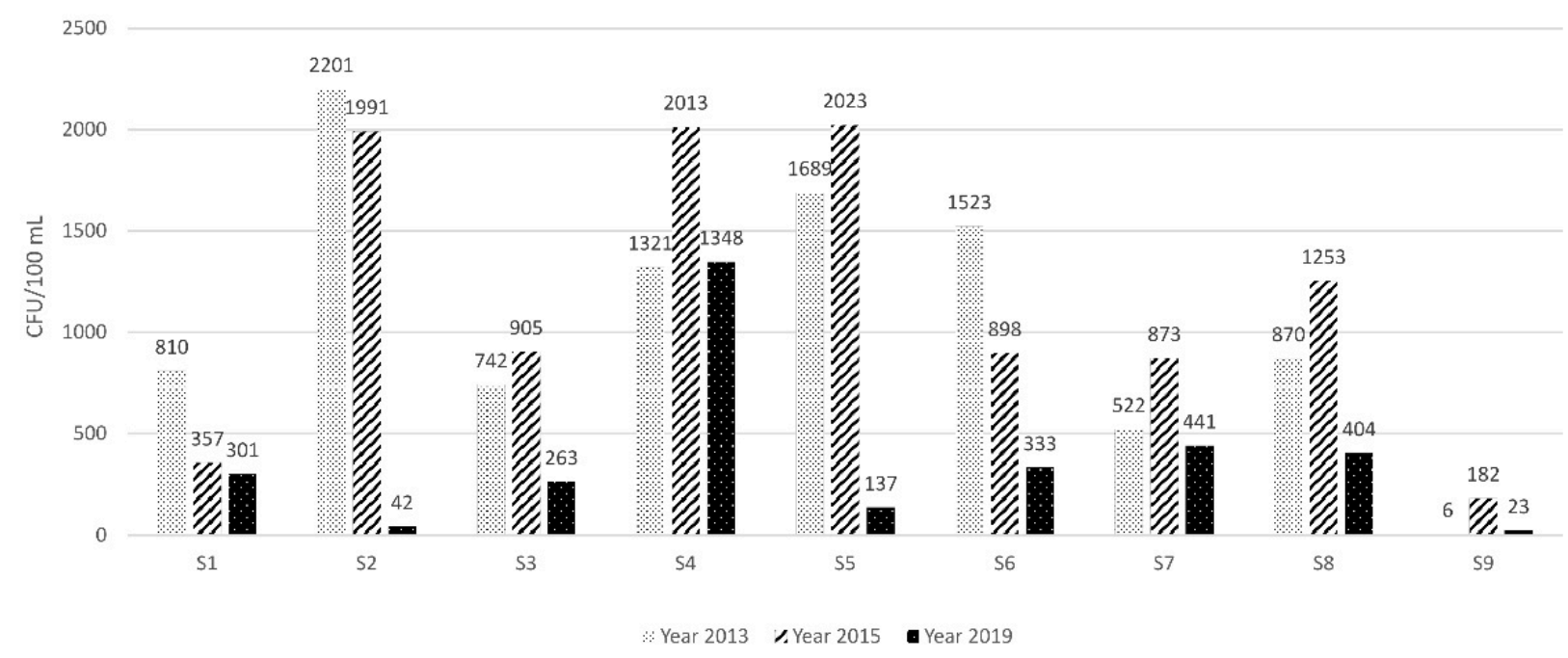

(A)

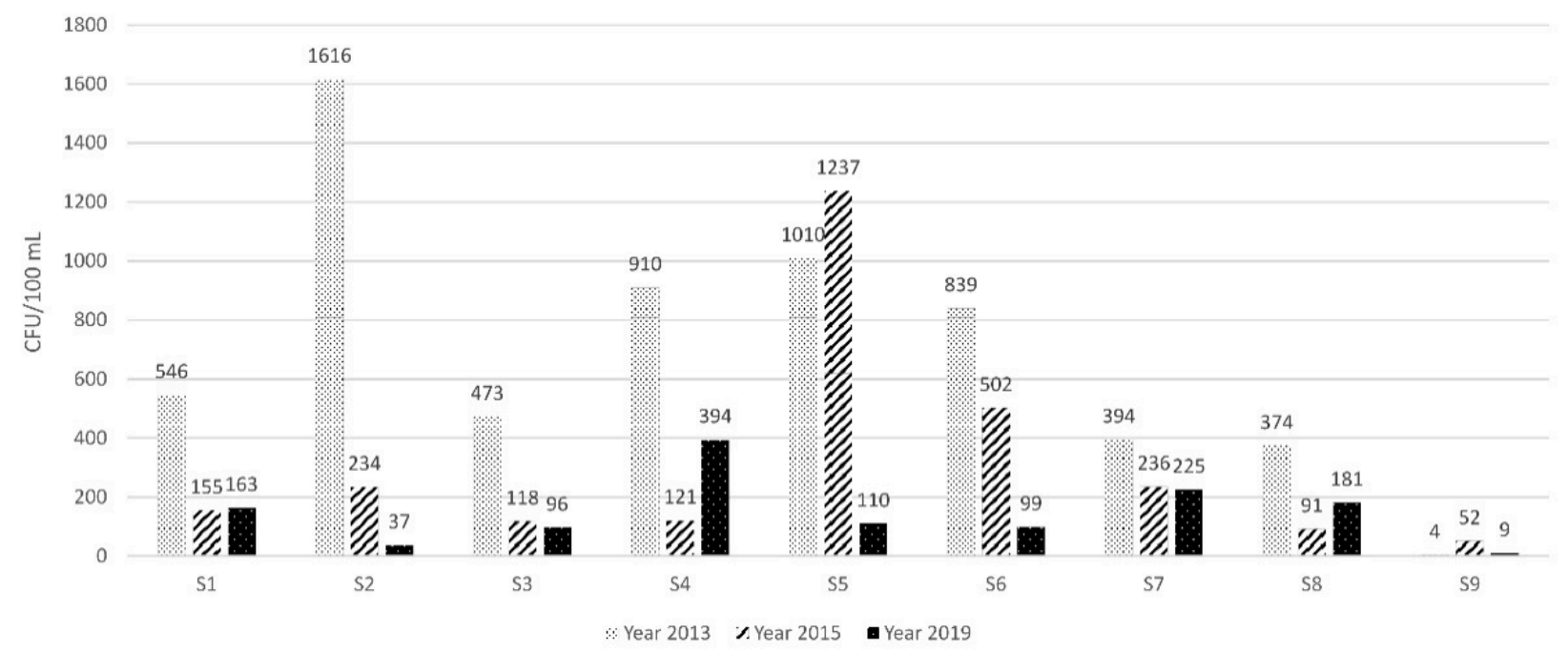

(B)

Figure 5. Spatial and temporal variation of total (A) and fecal (B) coliform bacteria densities of each sampling section from Sf. Gheorghe branch (S1 to S9) in sediments in2013, 2015 and 2019. All studies represent one of three independent experiments.

In most sampling sites, with the exception of S1, S2 and S5, the total coliforms densities in 2015 were higher than 2013 and 2019. S1, S2 and S5 have the lowest microbiological contamination for surface waters (Figure $4 \mathrm{~A}$ ).

Overall, the percent of fecal coliforms from the total coliforms was up to $75 \%$, compared to up to $93 \%$ in surface water. Another marking differences between surface waters and sediments could be observed on S9 (confluence with Black Sea) where the microbiological contamination in sediments was at the lowest level, regardless on sampling campaign from 2013 to 2019. Analyses performed of both types of samples (surface water and sediment) indicated low densities of coliform bacteria at $\$ 9$ point throughout the test period, with the exception of surface water in 2019, the explication being given by the change of conditions by the interference with the salt water of the Black Sea and also the production of a significant dilution.

The main issues that Danube and Danube Delta are still facing are high organic load (expressed COD and BOD), pathogenic microbial load, as well as the increase of antibiotic bacterial resistance, high concentrations of heavy metals (copper, nickel, zinc, mercury), organochlorine pesticides (lindane, DDT/DDE/DDDs), PAHs and PCBs, mostly detected in sediment [41]. 
In the next step of this study, we linked the increase of coliforms densities with their pathogenic and resistance potential of microorganisms. Over fiveEnterobacteriaceae strains were isolated from each control section from both water and sediment samples every year and a total of 648 isolated strains in the three years from which all potentially pathogenic and pathogenic bacteria were subjected to antibiograms and indicated the presence of particular resistance mechanisms. The ratio of total (TC) and fecal (FC) coliforms of the diameters of the inhibition zones for the microorganisms were tested according to the maximum limits allowed by CLSI indicated the existence of beta-lactam resistance mechanisms by the presence of Extended Spectrum of Beta-Lactamases (ESBLs), especially for CAZ, CRO and FEP. The most common bacterial strains identified by Omnilog system in both water and sediment samples during 2013, 2015 and 2019 were Escherichia coli, Klebsiella oxytoca, Citrobacter freundii and Proteus mirabilis. In most cases, approximatively $70 \%$ of them have been showed resistance to one or more antibiotics tested, but the results indicated that the diameter of inhibition zone decreases over time (Figure 6). This means that these strains increased their resistance to the antibacterial substance proving an ability to adapt over time. In many cases the diameter of the inhibition zone reached $0 \mathrm{~mm}$ for AMC and AMP during the years from 2013 to 2019, which means that the antibiotic had no effect on the bacteria which can develop under normal conditions in the presence of the antimicrobial agent (Figure 7).

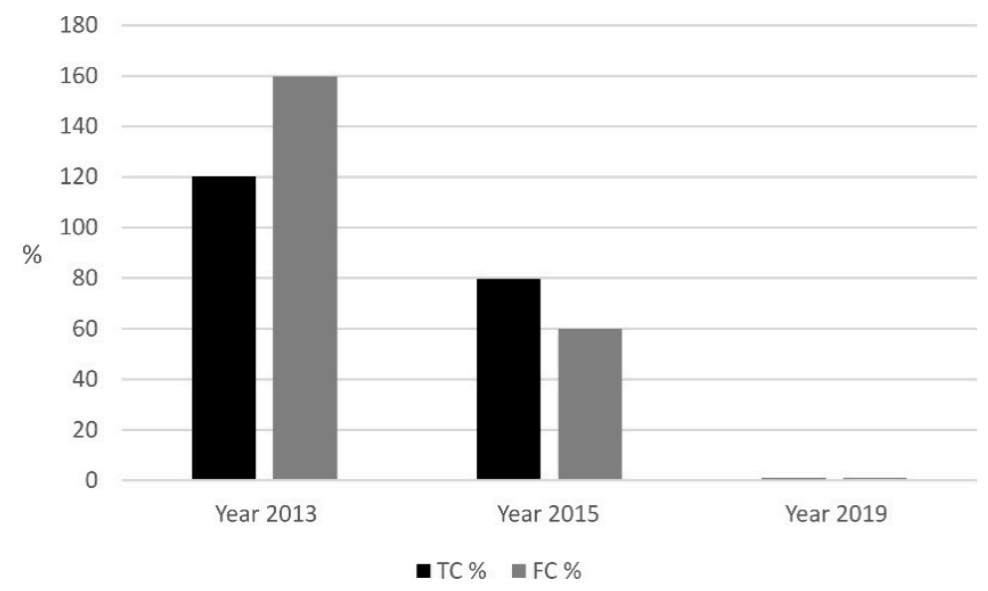

Figure 6. The ratio of total (TC) and fecal (FC) coliform bacteria in surface water and sediment during analysis period. All studies represent one of three independent experiments.

Overall, all antibiograms have shown the increase in the resistance profile over the years in a different manner, highlighting the growth of the multidrug resistance of bacterial strains. Moreover, during the study, phenomena of synergism and antagonism between beta-lactams could be observed, especially for AMP. Although carbapenems (IMP) are lifesaving antibiotics for the treatment of infections caused by antibiotic-resistant ram-negative bacilli, especially ESBL-producing enterobacteria, these tests demonstrate the resistance of Enterobacteriaceae to IMP, most likely due to the frequent use of this class of antibiotics.

If the recording of significant values of coliform bacteria density indicated a high degree of fecal pollution in certain areas of the studied zone, the presence of antibioticresistant and multidrug-resistant enterobacteria accentuated the pathogenic potential in the aquatic ecosystem. The mechanisms of pathogenicity and resistance can be easily transmitted among bacterial populations in the aquatic environment and can be supported by the intake of nutrients and antibiotics discharged so that the studied area can serve as a reservoir of antibiotic resistance genes. 


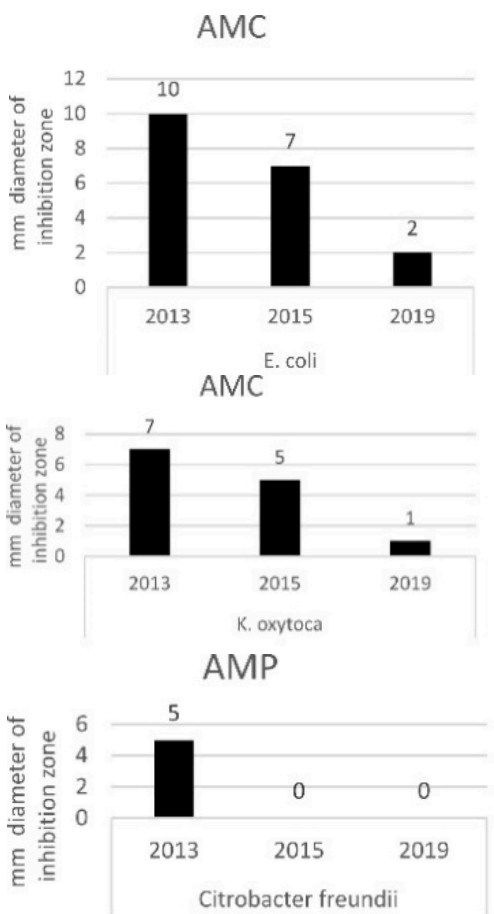

AMC

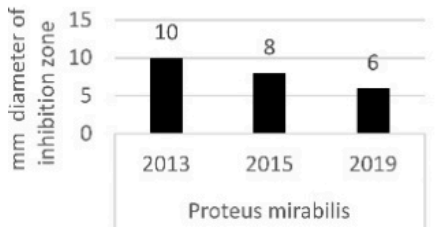

AMP

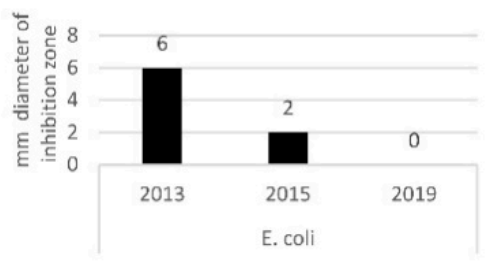

AMP

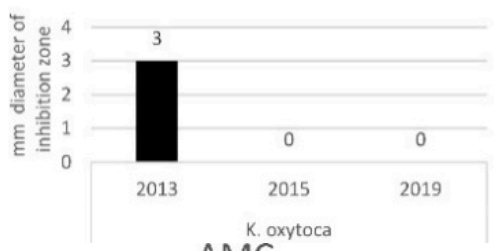

AMC
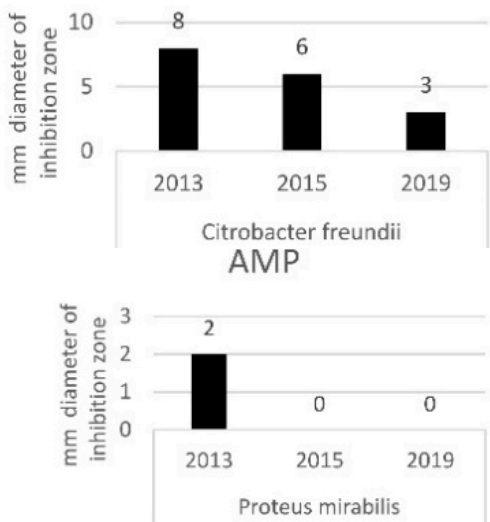

FEP

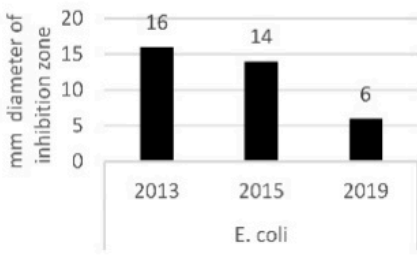

FEP

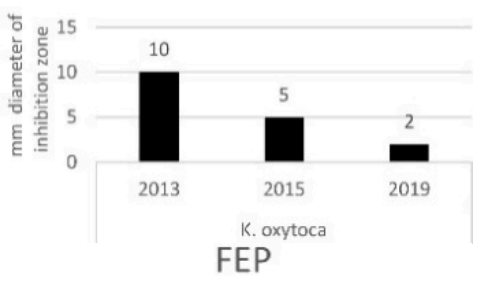

FEP

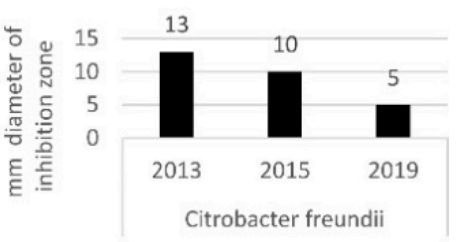

FEP

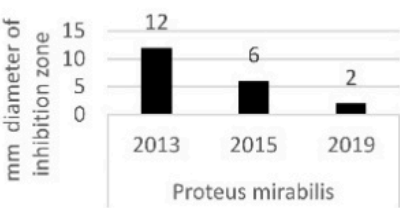

Figure 7. Diameters $(\mathrm{mm})$ of the antibiotic inhibition zones for the most common bacterial strains identified from surface water and sediment samples of St. Gheorghe branch in 2013, 2015, 2019. All studies represent one of three independent experiments.

\section{Conclusions}

Climate warming triggered by both natural and anthropogenic factors is a phenomenon unanimously accepted by the international scientific community, being already highlighted by the analysis of observational data over long periods of time.

This phenomenon was correlated with the microbiological pollution during 2013-2019 time period, in the Danube Delta aquatic ecosystem on Sf. Gheorghe branch. The global warming pattern during 2013-2019 overlapped the raise of microbiological contamination in the surface water and their antibiotic resistance in all nine sampling sites.

The differences between the bacterial densities from water and sediment showed the sedimentation effect of microorganisms by decreasing the density in water compared to that in the sediment.

The results of the S9 sampling point proved to be useful in demonstrating the influence of marine salinity on freshwater microorganisms by decreasing of total coliform bacteria number and also the effect of bacterial concentration dilution caused by currents formed at the confluence between the two categories of surface water.

Bacterial populations isolated and characterized have an antibiotic resistance potential to antibiotics, especially to AMP, AMC and FEP.

Overall, this study showed a continuous raise of the microbiological pollution which represent reservoirs of antibiotic-resistant bacteria, being detected bacteria with pathogenic potential that showed resistance to several beta-lactam antibiotics. 
Author Contributions: Conceptualization, A.R.B., M.N.-L. and C.I.C.; formal analysis D.L.I., M.A.V., D.M.R.; writing-original draft, A.R.B. M.N.-L. and C.I.C.; writing-review and editing, A.R.B., M.N.-L. and M.A.V. All authors have read and agreed to the published version of the manuscript.

Funding: This research was funded by Romanian Ministry of Research and Innovation projects code PN 09-13 02 10, PN 16-25 0105 and PN 19-04 0201.

Institutional Review Board Statement: Not applicable.

Informed Consent Statement: Not applicable.

Data Availability Statement: The data presented in this study are available on request from the corresponding author. The data are not publicly available due to ongoing research in this field.

Acknowledgments: This work was financially supported by PN 09-13 0210 (contract no. 13N/2009) and PN 16-25 0105 (contract no. 38N/2016) from the Ministry of Education and Research.

Conflicts of Interest: The authors declare no conflict of interest.

\section{References}

1. Sivanandham, V.; Krishnan, M.; Rathinam, A.J. Antibiotic resistant pathogens versus human impacts. A study from three eco-regions of the Chennai coast, southern India. Mar. Pollut. Bull. 2012, 64, 790-800. [CrossRef]

2. Palaniappan, M.; Gleik, P.H.; Allen, L.; Cohen, M.J.; Christian-Smith, J.; Smith, C. Cleaning the Waters: A Focus on Water Quality Solutions; UNEP: Nairobi, Kenya, 2010; p. 91.

3. Jorgensen, S.E.; Fath, B.D.; Bastianoni, S.; Marques, J.; Muller, F.; Nielsen, S.N.; Patten, B.; Tiezzi, E.; Ulanowicz, R. A New Ecology System Perspective, 1st ed.; Elsevier: Oxford, UK, 2007; pp. 1-2.

4. Cirtina, D. Aspects regarding surface water quality monitoring. Ann. Constantin Brancusi Univ. Targu-Jiu 2011, 1, 101-112.

5. Nita-Lazar, M.; Galaon, T.; Banciu, A.; Paun, I.; Stoica, C.; Lucaciu, I. Screening of various harmful compounds in a new bacterial biological model. J. Environ. Prot. Ecol. 2016, 17, 237-247.

6. Velimirov, B.; Milosevik, N.; Kavka, G.; Farnleitner, A.; Kirschner, A. Development of the bacterial compartment along the Danube River: A continuum despite local influences. Microb. Ecol. 2011, 61, 955-957. [CrossRef]

7. Savichtcheva, O.; Okabe, S. Alternative indicators of fecal pollution: Relations with pathogens and conventional indicators, current methodologies for direct pathogen monitoring and future application perspectives. Water Res. 2006, 40, $2463-2476$. [CrossRef]

8. Prisacari, V. Guide to the Surveillance and Control of Nosocomial Infections; USAID: Washington, DC, USA, 2008; ISBN 978-9975-106-19-1.

9. Wellington, E.M.; Boxall, A.B.; Cross, P.; Feil, E.J.; Gaze, W.H.; Hawkey, P.M.; Johnson-Rollings, A.S.; Jones, D.L.; Lee, M.N.; Otten, W.; et al. The role of the natural environment in the emergence of antibiotic resistance in Gram-negative bacteria. Infect. Dis. 2013, 13, 155-165. [CrossRef]

10. Van Van Hoek, A.H.A.M.; Mevius, D.; Guerra, B.; Mullany, P.; Roberts, A.P.; Aarts, H.J.M. Aquired antibiotic resistance genes: An overview. Front. Microbiol. 2011, 2, 203. [CrossRef]

11. Ferri, M.; Ranucci, E.; Romagnoli, P.; Giaccone, V. Antimicrobial resistance a global emerging threat to public health systems. Crit. Rev. Food. Sci. Nutr. 2015, 57, 2857-2876. [CrossRef] [PubMed]

12. Wang, W. Houseflies as a Potential Vectors for Antibiotic Resistant Bacteria. Ph.D. Thesis, Ohio State University, Columbus, OH, USA, 2013.

13. Mierla, M.; Romanescu, G.; Nichersu, I.; Grigoras, I. Hydrological Risk Map for the Danube Delta-A case study of Floods within the Fluvial Delta. IEEE J. Sel. Top. Appl. Earth Obs. Remote Sens. 2015, 8, 98-104. [CrossRef]

14. Gasparotti, C. The main factors of water pollution in Danube River basin. EuroEconomica 2014, 33, 91-106.

15. Pall, E.; Niculae, M.; Kiss, T.; Sandru, C.D.; Spinu, M. Human impact on the microbiological water quality of the rivers. J. Med. Microbiol. 2013, 62, 1635-1640. [CrossRef] [PubMed]

16. Navarro-Ortega, A.; Acuna, V.; Belin, A.; Burek, P.; Cassiani, G.; Chourk-Allah, R.; Doledec, S.; Elosegi, A.; Ferarri, F.; Ginebreda, A.; et al. Managing the effects of multiple stressors on aquatic ecosystems under water scarcity. The Global Aqua project. Sci. Total. Environ. 2015, 503-504, 3-9. [CrossRef]

17. Stoica, C.; Camejo, J.; Banciu, A.; Nita-Lazar, M.; Paun, I.; Cristofor, S.; Rocha Pacheco, O.; Guevara Lopez, M. Water quality of Danube Delta systems: Ecological status and prediction using machine-learning algoritms. Water. Sci. Technol. 2016, 73, $2413-2421$. [CrossRef]

18. Stoica, C.; Gheorghe, S.; Petre, J.; Lacaciu, I.; Nita-Lazar, M. Tools for assessing Danube Delta systems with macro invertebrates. EEMJ 2014, 13, 2243-2252. [CrossRef]

19. Florescu, L.; Parpala, L.; Dumitrache, A.; Moldoveanu, M. Spatial and temporal distribution of the zooplankton biomass in Sfantu Gheorghe Branch (the Danube Delta Romania) in relation to environmental factors. Trav. Mus. d'Historie Nturelle Grigore Antipa 2013, 56, 109-124. [CrossRef]

20. Ajeagah, G.; Cioroi, M.; Praister, M.; Constantin, O.; Palela, M.; Bahrim, G. Bacteriological and environmental characterization of the water quality in the Danube River basin in the Galati area of Romania. Afr. J. Microbiol. Res. 2012, 6, 292-301. [CrossRef] 
21. Stevens, M.; Ashbolt, N.; Cunliffe, D. Microbial Indicators of Water Quality: An NHMRC Dissemination Paper; National Health and Medical Council: Canberra, Australia, 2001; pp. 4-6.

22. Matyar, F.; Kaya, A.; Dincer, S. Antibacterial agents and havy metals resistance in Gram negative bacteria isolated from seawater, shrimp and sediment in Iskenderum Bay, Turkey. Sci. Total. Environ. 2008, 407, 279-285. [CrossRef]

23. Baquero, F.; Martinez, J.L.; Canton, R. Antibiotics and antibiotic resistance in water environments. Curr. Opin. Biotech. 2008, 19, 260-265. [CrossRef]

24. Pitout, J.D.D.; Nordmann, P.; Laupland, K.B.; Poirel, L. Emergence of Enterobacteriaceae producing extended spectrum $\beta$ lactamases (ESBLs) in the community. J. Antimicrob. Chemother. 2005, 56, 52-59. [CrossRef]

25. Antimicrobial Consumption in the EU/EEA. Available online: https://www.ecdc.europa.eu/sites/default/files/documents/ Antimicrobial-consumption-in-the-EU-Annual-Epidemiological-Report-2019.pdf (accessed on 21 November 2020).

26. ISO 19458:2007-Water Quality. Sampling for Microbiological Analysis. Available online: https://www.en-standard.eu/une-eniso-19458-2007-water-quality-sampling-for-microbiological-analysis-iso-19458-2006/ (accessed on 21 November 2020).

27. ISO 9308-2:1990—Water Quality. Detection and Enumeration of Coliform Organisms, Thermotolerant Coliform Organisms and Presumptive Escherichia coli-Part 2: Multiple Tube (Most Probable Number) Method. Available online: https://www.iso.org/ standard/16967.html (accessed on 21 November 2020).

28. CLSI 2012, M100-S22-Performance Standards for Antimicrobial Susceptibility Testing; Twenty-Second Informational Supplement. Available online: https:/ / www.scienceopen.com/document?vid=cafe92ec-d545-40a5-917d-0e960305bed0 (accessed on 21 November 2020).

29. Global Temperature Report for 2019. Available online: http:/ /berkeleyearth.org/2019-temperatures/ (accessed on 26 November 2020).

30. Fisher, M.; Graham, J.M.; Graham, L.E. Bacterial abundance and activity across sites within two northern Wisconsin Sphagnum bogs. Microbial. Ecol. 1998, 36, 259-269. [CrossRef] [PubMed]

31. Langenheder, S.; Jurgens, K. Regulation of bacterial biomass and community structure by metazoan and protozoan predation. Limnol. Oceanogr. 2001, 46, 121-134. [CrossRef]

32. Kent, A.D.; Jones, S.E.; Yannarell, A.C.; Graham, G.M.; Lanster, G.H.; Krantz, T.K.; Triplett, E.W. Annual patterns in bacterioplankton community variability in humic lake. Microbial. Ecol. 2004, 48, 550-560. [CrossRef]

33. Crump, B.C.; Kling, G.W.; Bahr, M.; Hobbie, J.E. Bacterioplankton community shifts in an Arctic lake correlate with seasonal changes in organic matter source. Appl. Environ. Microbiol. 2003, 69, 2253-2268. [CrossRef]

34. Banciu, A.; Niculescu, D.; Nita-Lazar, M.; Lucaciu, I.; Stoica, C.; Mihaescu, G. Potentialy pathogenic and antibiotic resistant bacteria in the Danube Delta aquatic ecosystem. J. Environ. Prot. Ecol. 2016, 17, 127-135.

35. Lazar, M.N.; Gheorghe, S.; Anghelache, A.; Banciu, A.; Stoica, C.; Lucaciu, I. Modulation of the bacteria defense mechanisms by various chemical structures. Rev. Chim. 2016, 67, 1454-1457.

36. Ouattara, N.K.; Passerat, J.; Servais, P. Fecal contamination of water and sediment in the rivers of the Scheldt drainage network. Environ. Monit. Assess. 2011, 183, 243-257. [CrossRef] [PubMed]

37. Ibecwe, A.M.; Leddy, M.B.; Bold, R.M.; Graves, A.K. Bacterial community composition in low-flowing river water with different sources of pollutants. FEMS Microbiol. Ecol. 2012, 79, 155-166. [CrossRef]

38. Lenart-Boroń, A.; Wolanin, A.; Jelonkiewicz, E.; Żelazny, M. The effect of anthropogenic pressure shown by microbiological and chemical water quality indicators on the main rivers of Podhale, southern Poland. Environ. Sci. Pollut. Res. 2017, 24, 12938-12948. [CrossRef] [PubMed]

39. Catrangiu, A.; Niculescu, D.; Lucaciu, I.; Chifiriuc, C.; Mihaescu, G. Virulence factors of Gram negative bacteria isolated from natural aquatic ecosystems. J. Environ. Prot. Ecol. 2015, 16, 33-39.

40. Bradley, W.C.; Owen, T.L. Multiple carbon substrate utilization by bacteria at the sediment-water interface: Seasonal patterns in a stratified eutrophic reservoir. Hydrobiologia 2007, 586, 43-56. [CrossRef]

41. Stoica, C.; Stanescu, E.; Paun, I.; Banciu, A.; Gheorghe, S.; Lucaciu, I.; Vasile, G.; Nita-Lazar, M. Danube Delta: Monitoring and ecological status. A link betweeknd the past and the future. RJEEC 2019, 1, 72-81. [CrossRef] 